\title{
THE EFFECT OF COMPETENCY, ORGANIZATIONAL INNOVATION AND WORKLOAD ON JOB SATISFACTION AND ITS IMPLICATIONS ON EMPLOYEE PERFORMANCE OF BPN ACEH
}

\author{
*Teuku Fazrul Afrizal, Mukhlis and Said Musnadi \\ Management Department, Universitas Syiah Kuala, Indonesia \\ http://doi.org/10.35409/IJBMER.2021.3265
}

\begin{abstract}
This study aims to determine The Effect Of Competency, Organizational Innovation, And Work Expenses On Job Satisfaction And Its Implications On The Performance Of Employees In the BPN Regional Office of Aceh Province (BPN Aceh), Indonesia. The population was all employees of the BPN Aceh which was 142 people, including permanent employees and temporary employees. Determination of the sample was carried out using census techniques, resulting in the same number as the population, namely 142 people. The questionnaire was used to collect the research data and used structural equation modeling (SEM) to analyze it with the help of the Amos software. The results prove that Competence significantly can affect employee job satisfaction, Organizational innovation significantly can affect employee job satisfaction, workload significantly can affect employee job satisfaction, Job satisfaction significantly can affect employee performance, Competence significantly can affect employee performance, Organizational innovation significantly can affect employee performance, Workload significantly can affect employee performance, competence can affect employee performance significantly through job satisfaction as a mediation, Organizational innovation can affect employee performance significantly through job satisfaction as mediation, and workload can affect employee performance significantly through job satisfaction as a mediation. These findings validate the model studied as a model for employee performance development in the BPN Aceh. Future researchers are expected to be able to use this research model as their reference and develop this model by adding variables such as human capital management and corporate citizenship behavior.
\end{abstract}

Keyword: Competence, Organizational Innovation, Workload, Job Satisfaction, and Employee Performance.

\section{INTRODUCTION}

The decline in employee performance in the BPN Regional Office of Aceh Province (BPN Aceh), in Indonesia, can also be seen from the quality of work that is still not following the Land Service and Regulatory Standards (SPPP) stipulated in the Regulation of the Head of the National Land Agency of the Republic of Indonesia Number 1 of 2010. The decline in employee performance can also be seen in the quantity of the number of certificates that can be completed by employees who have not reached the expected target. The decline in employee performance is 


\section{International Journal of Business Management and Economic Review}

Vol. 4, No. 03; 2021

ISSN: 2581-4664

also influenced by the lack of direct supervision by the leadership in the field.

The performance of employees in the BPN Aceh is influenced by their job satisfaction. In this study, job satisfaction is a mediating variable, which is the influence of other variables, which has implications for employee performance. Research conducted by (Ibrahim \& Lamuda, 2021) explained that job satisfaction owned by employees can have an influence in improving employee performance for the better. The variables that affect employee job satisfaction in the BPN Aceh in this study are limited to only the leadership variable applied by the leadership, then the level of employee work discipline is still relatively low and the work environment according to most employees has not been able to have an impact in increasing satisfaction work and employee performance.

In addition to job satisfaction factors, which can affect employee performance and organizational performance of the BPN Aceh, one of which is the competence possessed by employees. The low performance of employees at the BPN Aceh is inseparable from the influence of the low employee competency factor. The individual competence of employees at the BPN Aceh is relatively poor, this can be seen from the average value of 3.58 on the Likert scale unit, based on the perceptions or responses of employees to their competencies in order to improve individual performance and organizationally.

The decline in employee performance at the BPN Aceh is partly due to the lack of employee innovation in finding new ideas that are useful in completing work or innovation in providing services to the community. According to (Mulgan \& Albury, 2003), to more simply define innovation as new ideas that work, means that innovation is closely related to new useful ideas, the new nature of innovation will not mean anything if it is not followed by the useful value of its presence. Innovation is generally understood as a change in the behavior of employees.

Meanwhile, the workload variable for the BPN Aceh is relatively good because it has an average value greater than 3.41 on the Likert scale unit, this can be seen from the average value of 3.66 on the Likert scale unit. However, there are still indicators that have a value less than 3.41 , such as indicators of target size and indicators of standard provisions.

\section{LITERATURE REVIEW Employee Performance}

Employee performance is the result of an employee's work during a certain period compared to various possibilities, for instance, predetermined and mutually agreed standards, targets, or criteria, (Robbins \& Judge, 2017). This opinion explains that employee performance is the work produced by each member or employee in a certain period. Employee performance refers to a person's achievement as measured by the standards or criteria set by the company/organization.

Based on the definition above, it can be explained that performance or work performance is the result of work both in quality and quantity produced by an employee in a certain period following the given responsibilities.

Meanwhile, according to (Timpe, 2012) performance is the level of achievement of a person or employee in an organization or company that can increase productivity. Meanwhile, according to (Moenir, 2010) performance is the success that an individual can achieve in doing his job, where the measure of success achieved by an individual cannot be equated with other 


\section{International Journal of Business Management and Economic Review}

Vol. 4, No. 03; 2021

ISSN: 2581-4664

individuals. Employee performance is more directed at the level of employee performance. Someone works because there is something to be achieved and the activities that are carried out will lead to a condition that is more satisfying than the previous condition.

\section{Job Satisfaction}

Human resources will feel satisfied at work if the work and individual aspects support each other so that it can be said that job satisfaction is related to a person's feelings about whether the employee's job is fun or not. Job satisfaction is the employee's perception of how their job provides something that is considered important, which is important in the field of behavior.

Then job satisfaction according to (Miswar, Musnadi, \& Mahdani, 2015) is a pleasant or unpleasant emotional state towards work, job satisfaction reflects a person's feelings towards his job. According to (Brahmasari \& Suprayetno, 2008) job satisfaction is a problem that is quite interesting and important, because it has proven to be of great benefit to the interests of individuals, industry, and society. For individuals, research on the causes and sources of job satisfaction allows efforts to increase their happiness in life. For industry, research on job satisfaction is carried out in an effort to increase production and the effect of costs through improving employee attitudes and behavior.

Meanwhile, (Rahardjo, 2014) defined job satisfaction as a reflection of a person's feelings about his job. This can be seen in the positive attitude of employees towards their work and everything they face in their work environment. According to (Rahardjo, 2014) job satisfaction is an important issue that is considered concerning employee productivity and performance, and dissatisfaction is often associated with high levels of job demands and complaints.

\section{Competencies}

Individual competence in a simple sense is a combination of knowledge, skills, and attitudes. Every individual who occupies a certain position must have the required competencies, in order to be following the desired results.

According to (Oetomo, Wibowo, Hartono, \& Prakoso, 2007), said that every organization is formed to achieve certain goals and if it is achieved then it can be called a success. According to (Dobre, 2013), competence is the ability to carry out tasks following the knowledge and skills as well as technology and experience relevant to the task field so that it can develop the work motivation concerned and increase its performance.

According to (Rahardjo, 2014)Competence is the authority (power) to determine or decide something". Then according to (Ruslan, Mukhlis, \& Mahdani, 2015)that the overall competence of knowledge, skills, behavior, and attitudes displayed by people who are successful or successful in doing a task with optimal work performance.

\section{Organizational Innovation}

Innovation is something that has to do with goods, services, or ideas that are new to someone. (Rediyono \& Ujianto, 2013) stated that innovation is something that is often very complex. Environmental changes faced by companies provide an opportunity to give birth to something new and different through systemic innovation that requires organized and directed 


\section{International Journal of Business Management and Economic Review}

Vol. 4, No. 03; 2021

ISSN: 2581-4664

changes so as to provide opportunities to create both economic and social innovations. It is very important that should be owned by every organization.

Innovation in organizations is something new in the form of anything that happens in a formal or informal organization. The innovation that occurs in an organization is a process of progress of the organization, but various obstacles and obstacles will occur when the innovation starts to enter the organization. Understanding the innovation process in the organization will at least reduce organizational shock in implementing the diffusion of innovation.(Vathanophas \& Thai-ngam, 2007) argued that innovation refers to new products or efforts to make new breakthroughs.

\section{Workload}

The performance will be satisfactory if the workload allocated to each holder of an office or an employee who works in an organization is following the standards, neither too high nor too low. Workloads that are too heavy or light will have an impact on work inefficiency. The workload that is too light can make an employee bored with their duties that are considered too light and not challenging. This situation will make an employee feel that their abilities/expertise are not taken into account by the organization.

According to (Gustisyah, 2013) stated that workload is one of the aspects that must be considered by every company/organization, because workload affects employees in increasing productivity and feeling comfortable at work. The workload is a job demand that is owned daily and is considered as a source of burden. The meaning of the workload here can be divided into two, namely excessive workload (overload) and underload workload (Rivai \& Mukti, 2018).

Then according to (Meshkati, Eskandari, \& Mostahfezian, 2014) in (Rivai \& Mukti, 2018), the workload is defined as a difference between the capacity or ability of workers and the job demands that must be faced. According to (Lewa \& Subowo, 2005) workload includes physical and mental workloads. The workload is one of the elements that must be considered for a workforce to get harmony and high work productivity in addition to the additional load elements due to the work environment and work capacity (Shah et al., 2011).

\section{Previous Research}

Research conducted by (Azmi, Nasir, \& Sofyan, 2019) where the competencies possessed by employees are able to have an influence in improving employee performance at the Unsyiah Dental and Oral Hospital, Banda Aceh. Then the research conducted by (Ananda, Nasir, \& Musnadi, 2019) stated that organizational innovation has an influence in improving employee performance. Meanwhile, research conducted by (Idawani, 2018) stated that workload has an influence in improving the performance of Aceh PUPR Office employees.

\section{Research Hypothesis}

Several research hypotheses are determined in this research as follows.

H1 : Competence significantly can affect employee job satisfaction

$\mathrm{H} 2$ : Organizational innovation significantly can affect employee job satisfaction

H3 : workload significantly can affect employee job satisfaction

H4 : Job satisfaction significantly can affect employee performance

H5 : Competence significantly can affect employee performance 
Vol. 4, No. 03; 2021

ISSN: 2581-4664

H7 : Organizational innovation significantly can affect employee performance

H8 : Workload significantly can affect employee performance

H10 : competence can affect employee performance through job satisfaction significantly.

H11 : organizational innovation can affect employee performance significantly through job satisfactionas a mediation.

H12 : workload can affect employee performance significantly through job satisfaction as a mediation.

\section{METHOD}

\section{Location and Object}

The location of this research was carried out at the BPN Aceh. As for the objects of research are competence, organizational innovation, workload, job satisfaction, and employee performance.

\section{Population and Sample}

The population was all employees of the Aceh Provincial BPN Regional Office which may be 142 people, including permanent employees and temporary employees. Determination of the sample was carried out using census techniques, resulting in the same number as the population, namely 142 people.

\section{Data Analysis Tools}

Data analysis tools to test respondents' perceptions used descriptive tests based on the mean value of each variable, with the assumption that if the mean value is $<4$, it is perceived as poorly and if the mean value is $\geq 4$, it is well perceived by the respondent.

The appearance of a complex model implies that in reality the management decisionmaking process is a complex process or is a multidimensional process with various hierarchical patterns of causality. Therefore the authors need a model as well as an analytical tool that is able to accommodate this multidimensional research. So the structural equation modeling (SEM) was used to process the data in this research (Ferdinand, 2014).

\section{RESULT}

The full model SEM stage was carried out by performing a suitability test and statistical test, which are shown in the following figure: 
International Journal of Business Management and Economic Review

Vol. 4, No. 03; 2021

ISSN: 2581-4664

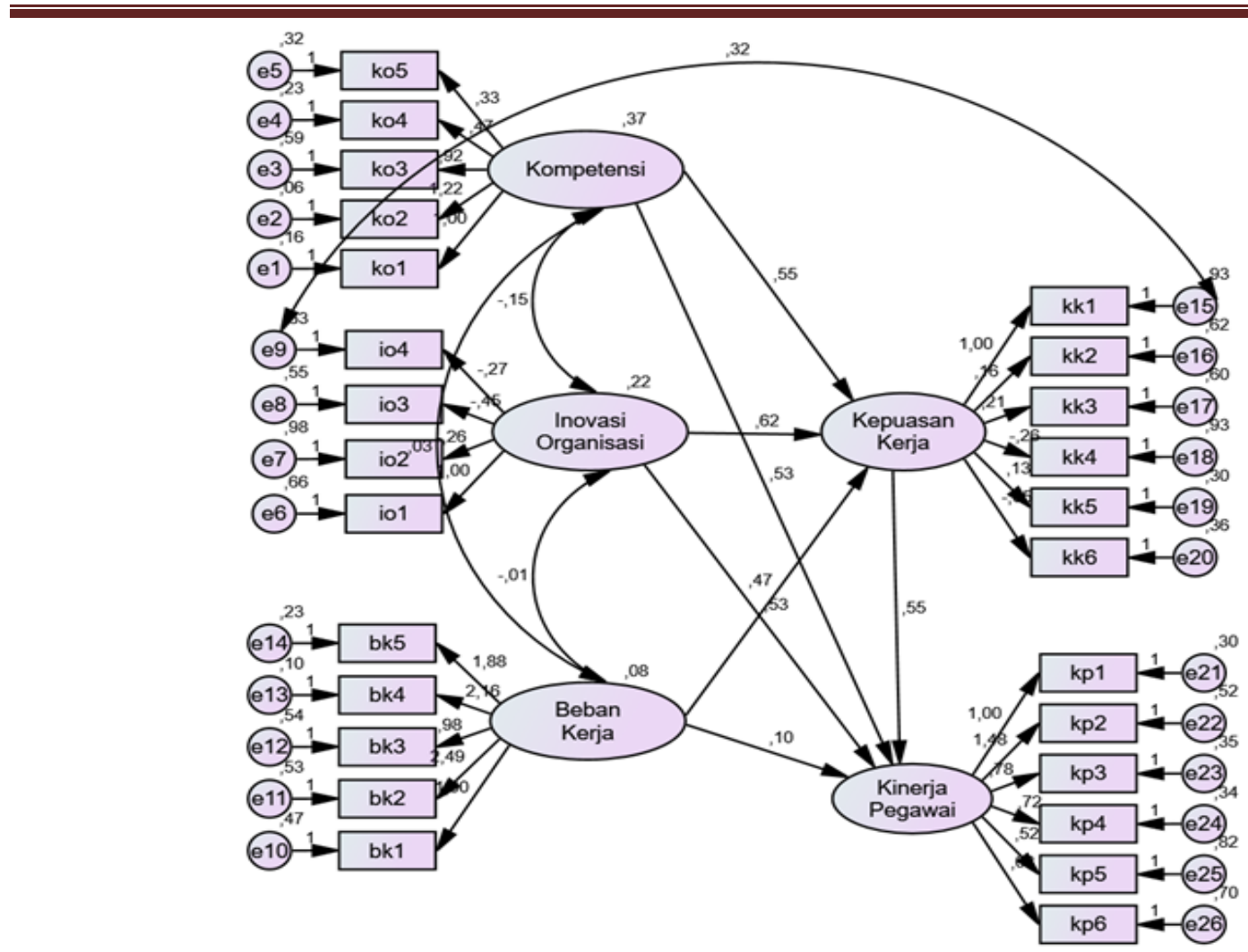

Figure 1. Test Result of Structural Equation Model (SEM)

\section{The Competence in Affectingthe Job Satisfaction}

The influence of competence on the job satisfaction test provides the critical ratio (CR) value of 9.733 and probability (p) value of 0.000 . The $\mathrm{CR}$ value is proved $>$ the $\mathrm{t}$-table value of 1.97 and the p-value $<0.05$. Both values explain that competence at the BPN Aceh influences on increasing job satisfaction of employees of the BPN Aceh.

\section{The Organizational Innovation in Affecting the Job Satisfaction}

The influence of organizational innovation on the employee job satisfaction test provides the CR value of 7.951 that is $>$ the $t$ table of 1.97 and the $p$-value $<0.05$. Both values reveal that organizational innovation possessed by the BPN Aceh employees affects on increasing job satisfaction of the BPN Aceh employees.

\section{The Workload in Affecting the Job Satisfaction}

The influence of workload on employee job satisfaction testprovides the CR valueof 7.367 which is $>$ the $t$-table value of 1.97 and the $p$-value $<0.05$. Both values describe that the workload assigned to employees will affect increasing job satisfaction at the BPN Aceh.

The Job Satisfaction in Affecting the Employee Performance

The influence of job satisfaction on the employee performance test provides the CR 


\section{International Journal of Business Management and Economic Review}

Vol. 4, No. 03; 2021

ISSN: 2581-4664

value of 8.235 , which is $>$ the t-table value of 1.97 and the p-value $<0.05$. Both values describe that job satisfaction affects the performance of employees at the BPN Aceh.

\section{The Competence in Affecting the Employee Performance}

The influence of competence on employee performance test provides theCR value of 8.763 which is $>1.97$ and the p-value $<0.05$. Both values conclude that the competence possessed by the employees of the BPN Aceh affects employee performance.

\section{The Organizational Innovation in Affecting the Employee Performance}

The influence of organizational innovation on employee performance test provides the $\mathrm{CR}$ value of 5.795 which is $>$ the t-table value of 1.97 and $p$-value $<0.05$. Both values reveal that the organizational innovation provided to employees at the BPN Aceh influences on improving the performance of the BPN Aceh employees.

\section{The Workload in Affecting the Employee Performance}

The influence of workload on employee performance test provides the CR value of 6.525 which is > of 1.97 and the p-value $<0.05$. Both values explain that the appropriate workload given to the BPN Aceh employees influences on improving employee performance at the BPN Aceh.

\section{The Competence in Affecting the Employee Performance Significantly Through Job} Satisfaction As A Mediation

The direct effect of the competency variable on job satisfaction, and also job satisfaction on employee performance are significant. With the evidence that all direct effects associated with this model are significant, it can be ascertained that job satisfaction in this model is a partial mediator. Meanwhile, testing the effect of competence on employee performance through the job satisfaction variable provides the number of 0.530 as a coefficient. This means that to improve the performance of employees, the leader can directly improveemployee competence, especially concerning employee skills and knowledge related to land information, and it will influence job satisfaction and lead to an increase in employee performance.

The Organizational Innovation in Affecting the Employee Performance significantly through job satisfaction as a mediation.

The direct effect of organizational innovation on job satisfaction, and also job satisfaction on employee performance are significant. With the evidence that all direct effects associated with this model are significant, it can be ascertained that job satisfaction in this model is a partial mediator. Meanwhile, the influence of organizational innovation influences employee performance through the job satisfaction variable provides the number of 0.537 as a coefficient. This means that to improve the performance of employees, the leader can provide or increase organizational innovation to employees and it will influence job satisfaction and lead to an increase in employee performance.

The Job Satisfaction in Affecting the Employee Performance significantly through job satisfaction as a mediation. 


\section{International Journal of Business Management and Economic Review}

Vol. 4, No. 03; 2021

ISSN: 2581-4664

The direct effect of workload variables on job satisfaction, and also job satisfaction on employee performance are significant. With the evidence that all direct effects associated with this model are significant, it can be ascertained that job satisfaction in this model is a partial mediator. Meanwhile, the effect of workload on employee performance through the job satisfaction variable provides the number of 0.105 as a coefficient. This means that to improve the performance of employees, the leader can provide a workload that is following the level of ability they have and their main duties in the office and it will influence job satisfaction and lead to an increase in employee performance.

\section{CONCLUSION}

The results prove that Competence significantly can affect employee job satisfaction, Organizational innovation significantly can affect employee job satisfaction, workload significantly can affect employee job satisfaction, Job satisfaction significantly can affect employee performance, Competence significantly can affect employee performance, Organizational innovation significantly can affect employee performance, Workload significantly can affect employee performance, competence can affect employee performance significantly through job satisfaction as a mediation, Organizational innovation can affect employee performance significantly through job satisfaction as mediation, and workload can affect employee performance significantly through job satisfaction as a mediation. These findings validate the model studied as a model for employee performance development in the BPN Aceh. This means that to improve employee performance in the BPN Aceh, it can be done by increasing and readjusting employee competence, organizational innovation, workload, and job satisfaction, either directly or indirectly according to the track that has been tested. The novelty lies in the combination of previous models of causality and testing them in the BPN Aceh. Future researchers are expected to be able to use this research model as their reference and develop this model by adding variables such as human capital management and corporate citizenship behavior.

Some suggestions are mapped for the practitioner in the BPN Aceh. In order to increase job satisfaction and employee performance, the needs to be increased are the ability of employees according to their work standards, the employee participation in creating innovation so that it has an impact on increasing their job satisfaction and better performance, an appropriate workload should be of concern to the leadership of the organization so that the workload is able to increase job satisfaction and increase employee performance, and the provision of job satisfaction to employees should be given in the form of awards to employees.

\section{REFERENCES}

Ananda, M. R., Nasir, \& Musnadi, S. (2019). The Effect of Organizational Learning on Organizational Performance through Mediations: Study in Government Secretariat of Pidie Jaya. East African Scholars Journal of Economics, Business and Management, 2(9), 480-485.

Azmi, I. N., Nasir, \& Sofyan. (2019). The Effect of Organizational Commitment and its Implications on Employee Performance in the Dental Hospital and Mouth of Universitas Syiah Kuala Banda Aceh. International Journal of Social Science \& Economic Research, 4(9).

Brahmasari, I. A., \& Suprayetno, A. (2008). Pengaruh Motivasi Kerja, Kepemimpinan dan 


\section{International Journal of Business Management and Economic Review}

Vol. 4, No. 03; 2021

ISSN: 2581-4664

Budaya Organisasi Terhadap Kepuasan Kerja Karyawan serta Dampaknya pada Kinerja Perusahaan (Studi kasus pada PT. Pei Hai International Wiratama Indonesia). Jurnal Manajemen Dan Kewirausahaan, 10(2), 124-135.

Dobre, O. I. (2013). Employee motivation and organizational performance. Review of Applied Socio-Economic Research, 5(1), 53-60.

Ferdinand, A. (2014). Metode Penelitian Manajemen (Edisi 5). Semarang: Universitas Diponegoro.

Gustisyah, R. (2013). Analisis Faktor-Faktor Yang Mempengaruhi Motivasi Kerja Penyuluh Perindustrian Pada Kantor Dinas Perindustrian Dan Perdagangan Kota Medan. Journal of Research in Marketing, 4(1).

Ibrahim, M., \& Lamuda, I. (2021). Human Resource Management Of Bureaucracy In Indonesia: Is It True That Job Satisfaction Increases Employee Performance? Psychology and Education Journal, 58(1), 3218-3231. https://doi.org/https://doi.org/10.17762/pae.v58i1.1263

Idawani, C. (2018). Pengaruh Kompetensi, Beban Kerja Dan Stres Kerja Terhadap Work Engagement Dan Implikasinya Pada Kinerja Dinas Pekerjaan Umum Dan Penataan Ruang Aceh. Syiah Kuala University.

Lewa, E. I. I. K., \& Subowo. (2005). Pengaruh Kepemimpinan, Lingkungan Kerja Fisik dan Kompensasi terhadap Kinerja Karyawan di PT. Pertamina (Persero) Daerah Operasi Hulu Jawa Bagian Barat, Cirebon. Sinergi: Kajian Bisnis Dan Manajemen, 7(1), 129-140. https://doi.org/https://doi.org/10.20885/js.v0i0.934

Meshkati, Z., Eskandari, B., \& Mostahfezian, M. (2014). The relationship between organizational justice, organizational citizenship behavior, and organizational trust: A case study of the employees of the department of youth and sports. Research in Sport Management and Psychology, 2(2), 39-44.

Miswar, E., Musnadi, S., \& Mahdani. (2015). Penerapan E-Kinerja Terhadap Peningkatan Disiplin Dan Motivasi Serta Implikasinya Pada Kinerja Pegawai Sekretariat Daerah Kota Banda Aceh. Jurnal Manajemen Pascasarjana Unsyiah, 1(1), 1-10.

Moenir, H. A. . (2010). Manajemen Pelayanan Umum di Indonesia (Cet.9). Jakarta: Bumi Aksara.

Mulgan, G., \& Albury, D. (2003). Innovation in the Public Sector. Retrieved from https://www.alnap.org/system/files/content/resource/files/main/innovation-in-the-publicsector.pdf

Oetomo, B. S. D., Wibowo, E., Hartono, E., \& Prakoso, S. (2007). Pengantar Teknologi Informasi Internet: Konsep dan Aplikasi. Yogyakarta: Andi.

Rahardjo, S. (2014). The Effect Of Competence, Leadership And Work Environment Towards Motivation And Its Impact On The Performance Of Teacher Of Elementary School In Surakarta City, Central Java. International Journal of Advanced Research in Management and Social Sciences, 3(6), 59-74. 


\section{International Journal of Business Management and Economic Review}

Vol. 4, No. 03; 2021

ISSN: $2581-4664$

Rediyono, \& Ujianto. (2013). Pengaruh Inovasi, Budaya Organisasi dan Teamwork terhadap Kinerja Manajerial Serta Implikasinya pada Kinerja Bank Perkreditan Rakyat di Provinsi Kalimantan Timur. DIE, Jurnal Ilmu Ekonomi \& Manajemen, 9(2), 103-119.

Rivai, V., \& Mukti, A. G. (2018). Performance Appraisal Cara Tepat dan Mudah Mengukur dan Menilai Kinerja Karyawan dalam Perusahaan (Edisi Keti). Depok: PT. RajaGrafindo Persada.

Robbins, S. P., \& Judge, T. A. (2017). Essential of Organisational Behaviour (14th ed.). New Jersey: Pearson.

Ruslan, Mukhlis, \& Mahdani. (2015). Pengaruh Kompetensi Pendidikan Dan Pelatihan, Motivasi Dan Disiplin Kerja Terhadap Kinerja Pegawai Serta Dampaknya Pada Kinerja Dinas Perindustrian Dan Perdagangan Aceh. Jurnal Manajemen Pascasarjana Unsyiah, 4(4), 1-10.

Shah, S. S. H., Jaffari, A. R., Aziz, J., Ejaz, W., Ul-Haq, I., \& Raza, S. N. (2011). Workload and Performance of Employees. Interdisciplinary Journal Of Contemporary Research In Business, 3(5), 256-267.

Timpe, A. D. (2012). Seri Manajemen Sumber Daya Manusia (A. D. Ti, Ed.). Jakarta: PT Elex Media Komputindo.

Vathanophas, V., \& Thai-ngam, J. (2007). Competency Requirements for Effective Job Performance in Thai Public Sector. Organization Behavior and Human Resource Management, 3(1), 45-70. https://doi.org/https://doi.org/10.7903/cmr.49 